\title{
THE EFFECTS OF PROCESSED RUBBER (Hevea brasiliensis) SEED MEAL ON THE CHEMICAL COMPOSITION OF RATION, FEED INTAKE AND NUTRIENTS DIGESTIBILITY IN RABBITS (Oryctolagus cuniculus)
}

\author{
Amandine MATHO1 ${ }^{\circledR}$, Michelle CIEMENI AIMEE1, Mama MOUCHILI 1, Kuietche Hervé MUBE1, Henry \\ DEFANG FUALEFAC ${ }^{1,2}$, Florence FONTEH ${ }^{1}$, Alexis TEGUIA ${ }^{1}$, and Joseph TCHOUMBOUE ${ }^{1}$ \\ ${ }^{1}$ Department of Animal Sciences, Faculty of Agronomy and Agricultural Sciences, University of Dschang, P.O. Box: 222 Dschang, Cameroon.
2 University of Buea, Higher Technical Teachers Training Collage (HTTC), Kumba, Cameroon.
}

『Email: amandine_matho@yahoo.com; (1) orciD: 0000-0002-2749-8115

Supporting Information

ABSTRACT: This study aimed at evaluating the influence of processed rubber (Hevea brasiliensis) seed meal (RSM) on the chemical composition of feed, feed intake and nutrients digestibility in rabbits. For the purpose, 30 female (local breed) rabbits with an average weight of $2.7 \pm 0.12 \mathrm{~kg}$ were randomly allotted to five dietary treatments ( 6 rabbits in 1 treatment). The feeding trial lasted for four weeks and the various rations were: negative control ration, not containing rubber seeds (R0-) and 4 different rations each containing $20 \%$ of the rubber seed meal (raw, toasted, soaked, and boiled respectively for R0+, R1, R2, and R3 rations). The rubber seed meal, faeces and feed sample were sun dried to constant weight, urine was also collected and a sample was used for chemical analysis. The results showed that the boiled seeds RSM exhibited the highest crude protein content $(20.61 \% \mathrm{DM})$ and the low concentration of anti-nutritional factors (ANFs) $(21.83 \mathrm{mg} / \mathrm{kg} \mathrm{HCn}$; $30.53 \% ; 21.26 \%$ and $3.67 \%$ respectively for hydrogen cyanide $(\mathrm{HCn})$, phenols, flavonoids and tannins) compared to seeds from other treatments. Animals receiving the ration with boiled rubber seed meal (BRSM) at $100^{\circ} \mathrm{C}$ for 45 minutes (R3) showed better feed intake and best rate of digestive utilization coefficients of dry matter, organic matter, crude protein and crude fibres $32.24 \%$; $38.55 \%$; $61.03 \%$ and $80.58 \%$ respectively. The ration containing the boiled rubber seeds for $\mathbf{4 5}$ min resulted in better nutrient intake and the best digestive utilization coefficients in rabbits.

Keywords: Digestibility, Hevea brasiliensis, Nutritional value, Rabbit, Rubber seed.

Abbreviations: UDTRF: University of Dschang Teaching and Research Farm; ANPROLA: Animal Production and Nutrition Laboratory; SOCAPALM: Cameroon Company of Palm Groves; RRSM: raw rubber seed meal. DM: Dry Matter, OM: Organic Matter, CP: Crude Protein, CF: Crude Fibre. TO: Ration not containing rubber seeds meal, RRSM: Control ration with 20\% untreated rubber seed meal, BRSM: Ration with $20 \%$ rubber seed meal soaked in boiling water for $\mathbf{4 5}$ minutes, SRSM: ration with $20 \%$ rubber seed meal soaked in water at room temperature for 72 hours, TRSM: ration with $20 \%$ toasted rubber seed meal for $\mathbf{4 5}$ minutes; ANOVA: Analysis of variance; SPSS: Statistical Package for Social Sciences.

\section{INTRODUCTION}

Food remains the major challenge for successful animal breeding (Niba et al., 2012). It represents 60-70\% of production costs in intensive farming (Defang et al., 2014). This could be explained by the regular increase in the price of conventional feedstuffs such as soybeans or soybean meal which is imported, and competition between human and livestock for this primary product. In this situation, some breeders in developing countries tend to reduce the incorporation rate of expensive and scarce ingredients in ration formulation, which could lead to an unbalanced feed and consequently to a poor expression of the genetic potential of animals. According to Akinmutimi (2007), the consequences of the above are the reduction in the animal protein production and then, insufficient animal protein consumption, due to the scarcity and high cost of animal products. The attention in animal nutrition in recent years has been centred mostly on the search for alternative feed ingredients which are cheaper, readily available, have potential to replace expensive conventional feedstuffs during period of shortage and has little or no competition with human dietary demand (Alao et al., 2017; Sugiharto et al., 2018).

Rubber seeds (Hevea brasiliensis) appear as one of the alternative non-conventional feedstuff of interest (lyayi et al., 2008). In Cameroon, rubber is produced for exportation and seeds are usually discarded causing environmental hazard. Rubber seeds are produced by the rubber tree (Hevea brasiliensis), belonging to the family of Euphorbiaceous. It is known and used for its latex, but its seeds can be used in animal feeding. Rubber seed is a capital non-conventional feedstuff, which has received scant research attention in fish feeding (Sharma et al., 2014; Suprayudi et al., 2015; Deng et al., 2015), layers (Atchibri et al., 2008), pregnant and lactating pigs (Koné et al., 2016), chickens (Aguihe et al., 2017) and ducks (Amanidja et al., 2019). Researchers have revealed that dried seeds of Hevea brasiliensis contain between 17- 25\% protein (Sharma et al., 2014), 50.2\% fat, $6.5 \%$ crude fibre, $3.6 \%$ ash and $18.2 \%$ carbohydrate, as well as reasonable 
amounts of mineral trace elements (Udo et al., 2018). However, variability in nutrient content will depend on the variety, age at harvesting, soil type, processing methods and storage of the by-product. Despite the acceptable protein rate, rubber seed meal is characterized by the presence of anti-nutritional factors (ANFs), specially cyanogen glycosides, whose metabolic end product is hydrogen cyanide, that impacts negatively the physio-metabolic responses (Sharma et al., 2014; Deng et al., 2015). Freshly harvested rubber seeds contain anti-nutritional factors such as tannins (0.07\%), oxalate $(0.18 \%)$, saponins $(0.76 \%)$ and phytate $(0.51 \%)$ and a toxic element that can create disorders when they are immediately introduced into animal feed; also it contributes to gastrointestinal issues and reduce metabolic activity when ingested (Thangaraj, 2016). It is the hydrocyanic acid (Syahruddin et al., 2014; Ahaotu, 2018), whose rate is $24.89 \%$ (Udo et al., 2018), similar to cassava cyanic acid (Udo et al., 2018). Hence, the processing of rubber seeds could reduce their antinutritional factors and consequently optimize their use in animal feed. It is with this in mind that this work was initiated in order to contribute to the valorisation of agricultural by-products in animal feeding. Specifically it was to evaluate the influence of processing rubber seeds on the anti-nutritional factor contents, nutritional values, chemical composition of the ration; feed intake and nutrients' digestibility in rabbits fed with rations containing seeds subjected to different treatments.

\section{MATERIALS AND METHODS}

\section{Study site}

The study was conducted at the rabbitry unit of the University of Dschang Teaching and Research Farm (UDTRF) and in the Animal Production and Nutrition Laboratory (ANPROLA) of the Dschang University, and under Ethical regulation of Dschang University for animal welfare in in vivo studies. The UDTRF is located between $5^{\circ} 44^{\prime}-05^{\circ} 36^{\prime}$ 'and $5^{\circ} 44 '-05^{\circ} 37$ North 'latitude and $10^{\circ} 06^{\prime}-09^{\circ} 94^{\prime}$ and $10^{\circ} 06^{\prime}-09^{\circ} 85$ 'East longitude, at an altitude of $1420 \mathrm{~m}$ from the West Cameroon Region. The mean annual rainfall is about $2000 \mathrm{~mm}$, the wet season last from march to November and the dry season from late November to early March.

\section{Experimental rabbits and housing and prophylaxis}

A total of 30 female (local breed) rabbits aged 5 - 6 months were used for the trial. The rabbits were managed intensively and housed individually in specially constructed metabolic cages (Californian type) measuring $60 \mathrm{~cm} \times 40 \mathrm{~cm}$ $\times 25 \mathrm{~cm}$ in dimension. The adaptation period lasted ten days, during which the rabbits were treated against parasitic infection with ivermectin ${ }^{\circledR}(0.2 \mathrm{ml} / \mathrm{kg}$ body weight $)$ subcutaneous and multivitamin added to their water.

Experimental design and management

For the digestibility trial, 30 rabbits were randomly allotted to each of the 5 dietary treatments 6 rabbits per treatment). Each of the rabbit formed an experimental unit. The experiment lasted for seven days. The rabbits had free access to feed and potable water.

\section{Plant material}

The rubber seeds were harvested in the rubber plantations of SOCAPALM ${ }^{\circledR}$ (Cameroon Company of Palm Groves) in the Moungo Division, Littoral Region. They were decorticated, separated into 4 batches and processed differently. First batch was sun dried, second batch was cooked, third batch was toasted and the fourth batch was soaked. The processed rubber seeds were separately hammer-milled prior to experimental diet formulation to produce the respective meals as raw rubber seeds meal (RRSM), soaked (SRSM), boiled RSM (BSRM) and toasted RSM (TRSM).

\section{Processing methods}

\section{Boiling/cooking}

Raw decorticated rubber seeds were put into a cooking pot containing boiling water. The content was allowed to boil for $\mathbf{4 5}$ minutes before the seeds were descanted. The boiled seeds were sun dried, milled and stored for further use.

\section{Toasting}

Raw decorticated rubber seeds were toasted in a metallic frying pan for $\mathbf{4 5}$ min. After cooling, they were sun dried, milled and stored for further use.

Soaking

Raw decorticated rubber seeds were soaked in water at the ambient temperature, inside a closed inoxidable metal drum for 72 hours, followed by draining. The soaked seeds were sun dried, milled and stored for further use.

\section{Chemical analyses}

Chemical compositions of the processed rubber seed meals were analysed using the methods of AOAC (2000). The determinations of some minerals' contents were carried out according to the methods described by Pauwels et al. (1992). While the anti-nutritional factors were evaluated: the cyanide contents as described by ISO 6703-2 (1984); tannins content by the Folin-Ciocalteu method (Govindappa et al., 2011); the content of total phenols by the method described by (Ramdé-Tiendrébéogo et al., 2012); the total flavonoid content using the aluminium chloride colorimetric method (Chang et al., 2002).

\section{Experimental diets}

Five experimental diets were formulated to meet the nutritional requirements of the rabbits. TO (negative control) diet was free of rubber seed meal, RRSM (positive control) contained $20 \%$ untreated RSM, while, BRSM, SRSM and TRSM respectively containing $20 \%$ of treated rubber seeds meal as presented in Table 1. 
Table 1 - Percentage composition and proximate analysed experimental rations.

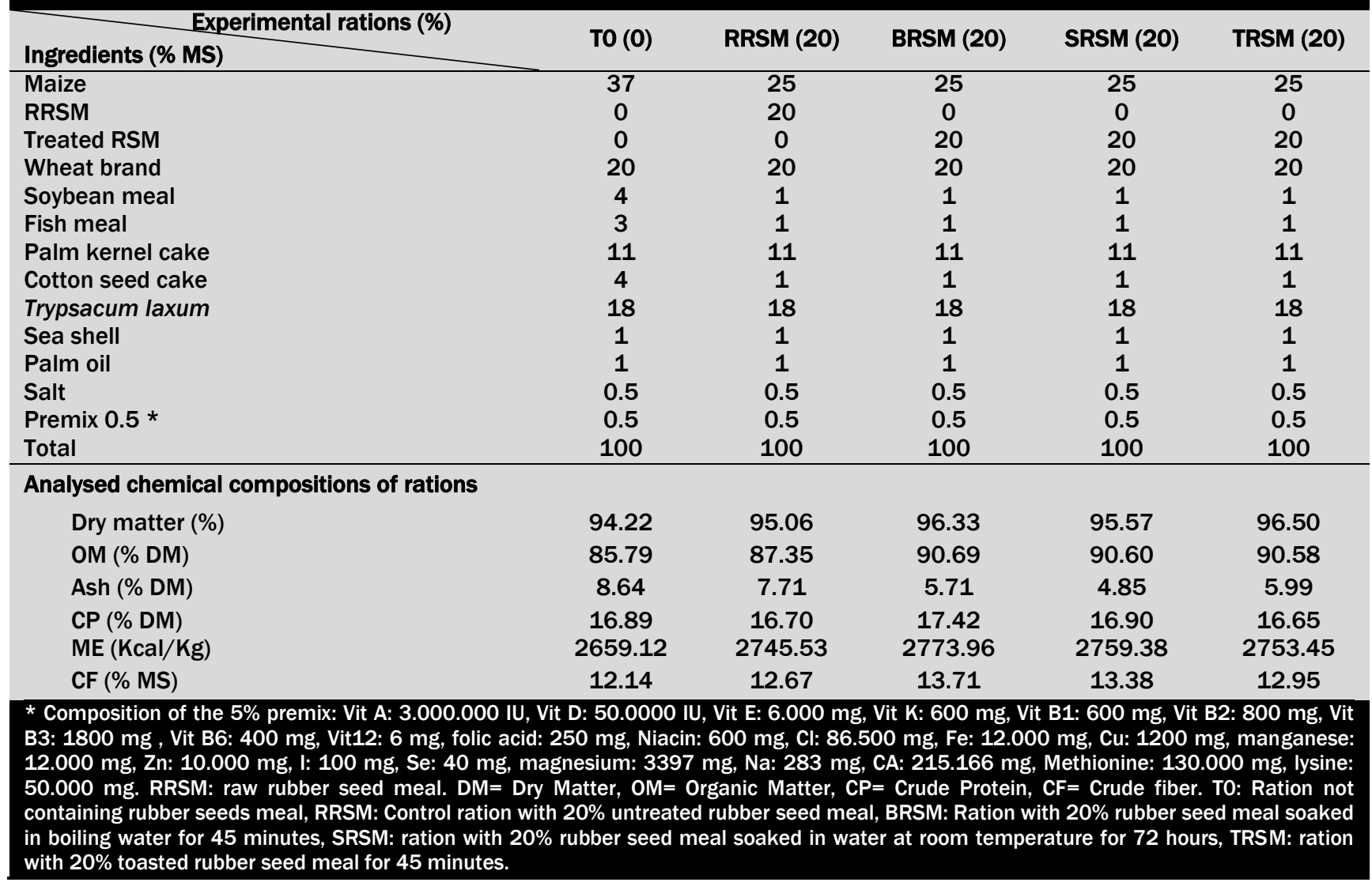

Data collection

\section{Metabolic cage trial}

During the experimental period, excreta and urine were collected daily for seven days. Faeces samples were pooled, weighed, dried, weighed again and ground. The nutrient composition of the faeces and urine samples was determined according to the procedures described by AOAC (2000). The resulting data were used to calculate the apparent nutrient digestibility coefficients.

\section{Statistical analysis}

Collected data were subjected to a one ways analysis of variance (ANOVA), using SPSS 20.0 software. Where there was a significant difference, Duncan's test at $5 \%$ significance was used to separate the means.

\section{RESULTS}

The effects of processing methods on anti-nutritional factors in raw and processed rubber seed meal (RSM) are presented on Table 2. Generally, processing had significant $(p<0.05)$ effects on ANFs. The ANFs in the boiled RSM was significantly $(p<0.05)$ lower compared to other treatments. However, flavonoids content $(21.26 \%)$ for BRSM remained comparable $(p>0.05)$ to that of TRSM (22.46\%).

\section{Effects of processing methods on proximate composition of raw and processed rubber seeds meals}

Table 3 presents the effects of processing methods on proximate composition of raw and processed rubber seeds meals. It appears that with the exception of toasting RSM, the treatments significantly $(p<0.05)$ improved the composition of the seeds meal. Boiled RSM had significantly $(p<0.05)$ higher results but its fat content and energy was the lowest. Toasted RSM despite the fact that its content in other nutrient components was significantly $(p<0.05)$ lower compared to untreated seeds, had the highest fat and energy contents.

\section{Effects of processing methods on minerals composition of raw and processed rubber seeds meal}

Table 4 shows the effects of processing methods on the minerals composition of raw and processed rubber seeds meal. Generally, the mineral contents in the processed RSM was significantly $(p<0.05)$ influenced by processing methods compared to the raw RSM. For macro minerals $(\mathrm{Ca}, \mathrm{K}$ and $\mathrm{P})$ boiled seeds meal had significantly $(p<0.05)$ higher values than that of the others treatment.

\section{Effects of processing methods of rubber seeds meal on feed intake in rabbits}

Table 5 presents the effects of rubber seeds treatments on rabbit feed intake. The ingestion of nutrients had significantly $(p<0.05)$ increased with the addition of rubber seeds in the ration compared to the TO ration (not containing rubber seeds). Nevertheless, feed ingestion of the dry matter and organic matter in animals fed RRSM diet was significantly lower $(p<0.05)$ than that of batch TO. The BRSM showed the significantly $(p<0.05)$ higher values. 
Table 2 - Effects of processing methods on anti-nutritional factors in rubber seeds meal.

\begin{tabular}{|c|c|c|c|c|c|c|}
\hline $\begin{array}{l}\text { Processed rubber seeds' meals } \\
\text { Anti-nutritional factors (ANFs) }\end{array}$ & RRSM & TRSM & SRSM & BRSM & SEM & $\mathbf{P}$ \\
\hline $\mathrm{HCn}(\mathrm{mg} / \mathrm{kg} \mathrm{HCn})$ & $87.34 \pm 0.00^{a}$ & $44.39 \pm 1.02^{b}$ & $30.57 \pm 2.06^{c}$ & $21.83 \pm 0.00^{d}$ & 2.12 & 0.001 \\
\hline Phenol (\%) & $90.71 \pm 0.07^{a}$ & $68.29 \pm 0.61^{b}$ & $43.53 \pm 0.10^{c}$ & $30.53 \pm 0.03^{d}$ & 6.97 & 0.01 \\
\hline Flavonoids (\%) & $45.47 \pm 0.15^{a}$ & $22.46 \pm 0.12^{c}$ & $43.14 \pm 1.10^{b}$ & $21.26 \pm 0.03^{c}$ & 3.39 & 0.001 \\
\hline Tanins (\%) & $16.04 \pm 0.04^{a}$ & $10.55 \pm 0.04^{b}$ & $5.63 \pm 0.07^{c}$ & $3.67 \pm 0.02^{d}$ & 1.44 & 0.001 \\
\hline
\end{tabular}

Table 3 - Effects processing methods on analysed proximate composition of raw and treated rubber seed meal (RSM).

\begin{tabular}{|c|c|c|c|c|c|c|}
\hline $\begin{array}{l}\text { Processed rubber seeds' meals } \\
\text { Parameters }\end{array}$ & RRSM & TRSM & SRSM & BRSM & SEM & $\mathbf{P}$ \\
\hline DM (\%) & $92.20 \pm 0.20^{b}$ & $89.20 \pm 0.20^{c}$ & $96.43 \pm 0.20^{a}$ & $92.00 \pm 0.01^{b}$ & 0.79 & 0.001 \\
\hline OM (\%) & $96.50 \pm 0.01^{b}$ & $95.68 \pm 0.09 c$ & $96.17 \pm 0.02^{b}$ & $97.53 \pm 0.07^{a}$ & 0.23 & 0.001 \\
\hline $\mathrm{CP}(\%)$ & $19.53 \pm 0.20^{b}$ & $18.39 \pm 0.20^{c}$ & $19.80 \pm 0.09^{b}$ & $20.61 \pm 0.15^{a}$ & 0.26 & 0.001 \\
\hline CF (\%) & $11.24 \pm 0.02^{d}$ & $14.99 \pm 0.04^{c}$ & $17.32 \pm 0.02^{b}$ & $18.90 \pm 0.05^{a}$ & 0.87 & 0.001 \\
\hline Fat (\%) & $37.04 \pm 0.08^{c}$ & $48.94 \pm 0.10^{a}$ & $42.17 \pm 0.03^{b}$ & $27.50 \pm 0.05^{d}$ & 2.36 & 0.001 \\
\hline Ash (\%) & $3.50 \pm 0.01^{c}$ & $2.31 \pm 0.09 d$ & $3.80 \pm 0.05^{b}$ & $4.43 \pm 0.07^{a}$ & 0.23 & 0.001 \\
\hline ME (Kcal) & $4526.61 \pm 1.90^{c}$ & $4835.57 \pm 1.84^{a}$ & $4826.29 \pm 0.05^{b}$ & $3939.44 \pm 0.61^{d}$ & 1.78 & 0.001 \\
\hline
\end{tabular}

Table 4 - Effects of processing methods on the mineral composition of raw and processed rubber seeds meal.

\begin{tabular}{|c|c|c|c|c|c|c|}
\hline $\begin{array}{l}\text { Processed rubber seeds' meals } \\
\text { Minerals (\%) }\end{array}$ & RRSM & TRSM & SRSM & BRSM & SEM & $\mathbf{P}$ \\
\hline $\mathrm{Ca}^{2+}$ & $0.09 \pm 0.01^{b}$ & $0.04 \pm 0.01^{c}$ & $0.02 \pm 0.00^{d}$ & $0.11 \pm 0.01^{a}$ & 0.011 & 0.001 \\
\hline $\mathrm{Mg}^{2+}$ & $0.29 \pm 0.03^{a}$ & $0.04 \pm 0.01^{c}$ & $0.27 \pm 0.02^{a}$ & $0.18 \pm 0.04^{b}$ & 0.030 & 0.001 \\
\hline$P$ & $0.24 \pm 0.01^{b}$ & $0.08 \pm 0.00^{d}$ & $0.20 \pm 0.01^{c}$ & $0.32 \pm 0.01^{a}$ & 0.025 & 0.001 \\
\hline $\mathrm{K}^{+}$ & $0.23 \pm 0.00^{b}$ & $0.15 \pm 0.01^{c}$ & $0.24 \pm 0.01^{b}$ & $0.29 \pm 0.01^{a}$ & 0.015 & 0.001 \\
\hline $\mathrm{Na}^{2+}$ & $0.02 \pm 0.00^{a}$ & $0.01 \pm 0.00^{b}$ & $0.02 \pm 0.00^{a}$ & $0.02 \pm 0.00^{a}$ & 0.001 & 0.001 \\
\hline
\end{tabular}

a. b. c. d. e: the means bearing the same letters in the same row are not significantly different at the threshold of $5 \%$. RRSM: Raw Rubber Seed

Meal; TRSM: Toasted Rubber Seed Meal; SRSM: Soaked Rubber Seed Meal; BRSM: Boiled Rubber Seed Meal; SEM: standard error on mean; p: probability; $\mathrm{Ca}^{2+}$ : calcium, $\mathrm{Mg}^{2+}$ : magnesium, $\mathrm{P}$ : phosphorus, $\mathrm{K}^{+}$: potassium, $\mathrm{Na}^{2+}$ : sodium.

Table 5 - Effects of processed rubber seed meal on rabbit feed intake.

\begin{tabular}{|c|c|c|c|c|c|c|c|}
\hline \multirow{2}{*}{ Feed intake } & \multirow{2}{*}{ TO } & \multicolumn{6}{|c|}{ Processed rubber seeds' meals } \\
\hline & & RRSM & TRSM & SRSM & BRSM & SEM & $\mathbf{P}$ \\
\hline DM (g) & $114.90 \pm 0.29^{d}$ & $110.35 \pm 0.67^{e}$ & $116.67 \pm 0.12^{c}$ & $118.53 \pm 0.36^{b}$ & $125.17 \pm 0.39^{a}$ & 1.30 & 0.001 \\
\hline OM (g) & $108.46 \pm 0.26 c$ & $102.85 \pm 0.69^{d}$ & $109.77 \pm 0.31^{b}$ & $110.27 \pm 0.34^{b}$ & $121.64 \pm 0.41^{a}$ & 1.63 & 0.001 \\
\hline $\mathrm{CP}(\mathrm{g})$ & $19.24 \pm 0.31^{d}$ & $20.33 \pm 0.29 c$ & $20.58 \pm 0.70^{c}$ & $21.10 \pm 0.59^{b}$ & $22.01 \pm 0.13^{a}$ & 0.24 & 0.001 \\
\hline CF (g) & $16.33 \pm 0.20^{c}$ & $18.10 \pm 0.19^{b}$ & $18.90 \pm 0.37^{a}$ & $18.98 \pm 0.19^{a}$ & $19.06 \pm 0.30^{a}$ & 0.28 & 0.001 \\
\hline
\end{tabular}

a. b. c. d. e: the means bearing the same letters in the same row are not significantly different at the threshold of $5 \%$; SEM: standard error on mean; p: probability; DM: dry matter; OM: organic matter; PB: crude protein; CB: cellulose brute. TO: Ration not containing rubber seeds meal; RRSM: Control ration with 20\% untreated rubber seed meal; TRSM: ration with 20\% toasted rubber seed meal for 45 minutes; SRSM: ration with $20 \%$ rubber seed meal soaked in water at room temperature for $\mathbf{7 2}$ hours; BRSM: Ration with $20 \%$ rubber seed meal soaked in boiling water for $\mathbf{4 5}$ minutes.

Effects of processing methods of rubber seeds' meal on the apparent digestibility of nutrients in rabbits

Table 6 summarises the effects of processed rubber seeds meal on the nutrients digestibility in rabbits. In general, there were significant $(p<0.05)$ differences in the apparent digestibility coefficient $(A D C)$ of $D M, O M, C P$ and $C F$ on the control diets. Additionally, the apparent digestibility coefficient of DM, MO, CP significantly $(p<0.05)$ increased for the rations containing processed RSM (TRSM, SRSM and BRSM) compared to the control ration (T0) and that containing untreated rubber seeds (RRSM). However, the apparent digestibility coefficient of all nutrients decreased significantly $(p<0.05)$ for the RRSM ration except that of crude protein which remained comparable to that of the TO ration. 


\section{Effects of processing methods of rubber seeds on nitrogen balance}

Table 7 shows the effects of processing rubber seeds meal on the apparent digestibility of nutrients and nitrogen balance. Processing significantly $(p<0.05)$ influenced ingestion and digestibility of nitrogen. Ration containing the boiled RSM had the better results however the nitrogen content ingested was comparable among rations. The apparent digestibility of nitrogen was better with the ration containing boiled rubber seeds $(30.29 \%)$.

\section{Table 6 - Effects of processed rubber seed meal on the apparent digestibility of nutrients in rabbits.}

\begin{tabular}{|c|c|c|c|c|c|c|c|}
\hline \multirow{2}{*}{ ADC (\%) } & \multirow{2}{*}{ TO } & \multicolumn{6}{|c|}{ Processed rubber seeds' meals } \\
\hline & & RRSM & TRSM & SRSM & BRSM & SEM & $\mathbf{P}$ \\
\hline DM & $21.16 \pm 0.14^{c}$ & $18.90 \pm 0.67^{d}$ & $26.79 \pm 0.26^{b}$ & $28.80 \pm 0.36^{b}$ & $32.24 \pm 2.47^{a}$ & 1.33 & 0.001 \\
\hline OM & $18.15 \pm 1.33^{c}$ & $14.68 \pm 0.26^{d}$ & $31.10 \pm 0.73^{b}$ & $32.34 \pm 0.45^{b}$ & $38.55 \pm 1.93^{a}$ & 2.42 & 0.001 \\
\hline $\mathrm{CP}$ & $55.02 \pm 2.48^{b}$ & $56.07 \pm 0.21^{b}$ & $55.46 \pm 0.80^{b}$ & $60.30 \pm 1.07^{a}$ & $61.03 \pm 1.81^{\mathrm{a}}$ & 0.75 & 0.001 \\
\hline CF & $64.86 \pm 1.83^{b}$ & $53.84 \pm 1.51^{d}$ & $57.63 \pm 2.71^{c}$ & $80.57 \pm 0.11^{a}$ & $80.58 \pm 0.67^{a}$ & 3.02 & 0.001 \\
\hline
\end{tabular}

a. b. c. d. e: the means bearing the same letters in the same row are not significantly different at the threshold of $5 \%$; SEM: standard error on mean; p: probability; ADC: apparent digestibility coefficient; DM: dry matter; OM: organic matter; CP: crude protein; CF: Crude fiber. T0: Ration not containing rubber seeds meal; RRSM: Control ration with $20 \%$ untreated rubber seed meal; TRSM: ration with $20 \%$ toasted rubber seed meal for 45 minutes; SRSM: ration with $20 \%$ rubber seed meal soaked in water at room temperature for 72 hours; BRSM: Ration with $20 \%$ rubber seed meal soaked in boiling water for $\mathbf{4 5}$ minutes.

\section{Table 7- Effect of processed rubber seeds meal on the digestive system of nitrogen.}

\begin{tabular}{|c|c|c|c|c|c|c|c|}
\hline \multirow{2}{*}{ Nitrogen $(\mathrm{N})$ balance $(\mathrm{g} / \mathrm{j})$} & \multirow{2}{*}{ TO } & \multicolumn{6}{|c|}{ Processed rubber seeds' meals } \\
\hline & & RRSM & TRSM & SRSM & BRSM & SEM & $\mathbf{P}$ \\
\hline Intake nitrogen & $2.51 \pm 0.13^{a}$ & $2.45 \pm 0.17^{a}$ & $2.52 \pm 0.05^{a}$ & $2.60 \pm 0.53^{a}$ & $2.62 \pm 0.03^{a}$ & 0.02 & 0.34 \\
\hline Faecal nitrogen & $1.28 \pm 0.02^{c}$ & $1.05 \pm 0.19^{d}$ & $1.52 \pm 0.08^{b}$ & $1.59 \pm 0.07 \mathrm{ab}$ & $1.77 \pm 0.11^{a}$ & 0.07 & 0.001 \\
\hline Urinary nitrogen & $0.41 \pm 0.02^{c}$ & $0.43 \pm 0.01^{c}$ & $0.53 \pm 0.02^{b}$ & $0.38 \pm 0.05^{c}$ & $0.64 \pm 0.06^{a}$ & 0.02 & 0.001 \\
\hline Retention nitrogen & $0.73 \pm 0.05^{a}$ & $0.36 \pm 0.01^{d}$ & $0.46 \pm 0.02^{c}$ & $0.62 \pm 0.01^{b}$ & $0.74 \pm 0.04^{a}$ & 0.04 & 0.001 \\
\hline ADC (\%) & $29.25 \pm 1.65^{a}$ & $13.16 \pm 0.31^{d}$ & $18.20 \pm 0.54^{c}$ & $24.07 \pm 0.31^{b}$ & $30.29 \pm 0.72^{a}$ & 1.69 & 0.001 \\
\hline
\end{tabular}

a. b. c. d. e: the means bearing the same letters in the same row are not significantly different at the threshold of $5 \%$; SEM: standard error on mean; p: probability; T0: Ration not containing rubber seeds meal; RRSM: Control ration with $20 \%$ untreated rubber seed meal; TRSM: ration with $20 \%$ toasted rubber seed meal for $\mathbf{4 5}$ minutes; SRSM: ration with $20 \%$ rubber seed meal soaked in water at room temperature for 72 hours; BRSM: Ration with $20 \%$ rubber seed meal soaked in boiling water for $\mathbf{4 5}$ minutes.

\section{DISCUSSION}

The HCn content of the fresh RSM $(87.34 \mathrm{mg} / \mathrm{kg})$ was lower than $186 ; 415.10$ and $315.89 \mathrm{mg} / \mathrm{kg}$ values reported by Eka et al. (2010), Sharma et al. (2014) and Aguihe et al. (2017) respectively. This result supports the report of (JECFA, 1993) that genetic and environmental factors, location, season, and soil factors are reasons for the wide variations observed in the ANFs. Moreover, reduction in the level of ANFs was effective with the adopted processing methods and this revealed that cyanide, tannins, phenol and flavonoids level in the raw seeds decreased for soaked, toasted, and boiled processing techniques. The highest level of reduction was obtained in the boiled seeds followed by soaked seeds and this is in agreement with previous researchers (Sharma et al., 2014) who stated that heat treatments and fermentation tends to reduce the concentration of ANFs in RRSM and makes them nutritionally less active. The finding corresponds with the description that anti-nutritional factors are heat liable (Eka et al., 2010; Aguihe et al., 2017; Udo et al., 2018) factors, this could be explained by the fact that the heat would have destroyed part of the ANFs and the water cooking would have washed out other ANFs. This result corroborates with that of Ogundipe et al. (2008), which showed that $71.91 \%$ of tannin is destroyed after 30 minutes of boiling the seeds by Mucuna. Similarly Chakam (2006) concluded that cooking is the best treatment for detoxify cowpea seeds. Soaked seeds take second place for this low content, then follow the toasted seeds. This could be explained by the unique action of heat on the one hand (toasting) and water on the other hand (soaking) or in the treatment by boiling the two factors interact.

The crude protein (CP) value of the raw rubber seed (19.53\% DM) obtained in this study was in agreement with the results of Lalabe (2017) but higher than $17.41 \%$ as reported by Eka et al. (2010). The crude fibre content (11.24\%) obtained in this trial is in agreement with that of Nwokolo (1988) (10.3\% DM), but significantly higher than that of Aguihe et al. (2017) and Udo et al. (2018) who obtained 4.40; 5.61; 5.88\% DM respectively. The variations observed could be attributed to the differences in variety of rubber trees, soil composition, climatic conditions as well as agricultural practices or plan mechanism meant for absorption of nitrogenous nutrients and inadequate fertilizer application of the rubber plantation (Chanjula et al., 2010). Also it can be explained by the processing and analysis methods used by these authors. The boiling of rubber seeds exhibited the greatest crude protein content while that the toasting presented the smallest value, this corroborates the results of Udo et al. (2018) who reported an increase in crude protein content when 
rubber seeds were boiled and a reduction in this content when toasted. The differences could be due to the effect of heat, which denatured part of the proteins during the two treatments.

The minerals contents of the raw seed were lower than that of Udo et al. (2018) with 1740 and $2066 \mathrm{mg} / \mathrm{kg}$ for calcium and magnesium respectively. Likewise, the minerals content of raw rubber seeds meal (RRSM) is lower than that obtained by Far et al. (2019). These differences may be attributed to genetic variations, as well as climate, environmental and geographical factors. The increase in minerals after boiling would be due to the fact that the minerals trapped by the anti-nutritional factors were released by heat. This result is in agreement with that of Udo et al. (2018) and that of Far et al. (2019) who both noted an increase in the minerals when boiling and a reduction in these when toasting the rubber seeds. The best results were registered with the boiled RSM with regard to the calcium, potassium, sodium and phosphorus contents and with the treatments SRSM and RRSM for magnesium.

Intake of nutrients were significantly higher for rabbits fed boiled RSM this could be explained by the fact that the boiling time was an effective treatment to reduce trypsin inhibitors, cyanide, saponins, and tannins (Chakam, 2006). The result of this trial is in agreement with the findings of Aguihe et al. (2017) and Far et al. (2019) who noted a better intake of the ration containing boiled rubber seeds meal.

The apparent digestibility coefficient of dry matter (DM) and organic matter (OM) were significantly higher for rabbits fed diet containing boiled rubber seed meal compared to the rest of the treatments. These results are lower than those of Lounaouci-Ouyed (2014), who obtained a load digestive factor from dry matter (79.8\%; 75.8\%; 78.2\%) and organic matter (79.2\%; $75.6 \%$ and $78.0 \%$, when rabbits were fed soybeans, peas and faba bean as sources of protein respectively. Likewise Cunha (1993) obtained a digestive utilization coefficient of the dry matter of $60.9 \%$ and an apparent digestibility coefficient of the organic matter of $61.4 \%$ when soybean was replaced at $20 \%$ by Vicia benchalensis in the rabbit ration. Indeed, these results could be due to the effects of the chemical composition of the ration, sex, age and breed, since digestibility depends on these factors. In fact, Cunha (1993) worked with animals of 3 months, of New Zealand breed. While in this study the animals used were 5 to 6 months. The apparent digestibility coefficient of crude protein (CP) and crude fibre (CF) were comparable for rabbits fed with RRSM soaked in water at room temperature for 72 hours but significantly higher compared with the rest of the treatment. The results obtained within these framework were lower than those obtained by Aguihe et al. (2017) (72.54\%) when broilers were fed a ration containing boiled rubber seeds; but comparable to those of Wafar et al. (2017), who obtained a digestibility coefficient of (60.45\%) when rabbits were fed raw kapot tree seeds. The best coefficient of digestibility of crude cellulose was obtained with the ration containing the boiled rubber seeds meal (BRSM), a result comparable to that of Wafar et al. (2017) (58.14\%), but higher than that of Aguihe et al. (2017) (43.47\%). This difference could be due to the chemical composition of the ration and the animal species, which agrees with Riviére's assertion (Rivière, 1991), which showed that feed and animal species strongly influence digestibility of nutrients.

This apparent digestibility coefficient of nitrogen was comparable to that of ration R0- not containing rubber seeds (29.25\%); but higher than that of the ration containing untreated seeds (13.16\%). This could be explained by the presence of anti-nutritional factors in the latter that would have interfered with digestive use nitrogen.

\section{CONCLUSION}

The results of the present research showed that boiling rubber seed is effective in reducing anti- nutrients factors in rubber seed. Also, the contents of dry matter, organic matter, proteins, crude fibre, ash and energy increased with treatment boiling rubber seed meal. The best results of ingestion and digestibility coefficient of the components of the ration were obtained with the ration containing the boiled RSM. The processing treatments used in this work caused reduction at different rates in the level of anti-nutrients present in the raw seed of Hevea brasiliensis to tolerable level safe for consumption.

\section{DECLARATIONS}

Corresponding author's Email: amandine_matho@yaho.com

Acknowledgements

Authors gratefully thank Pr. KANA Jean-Raphaël and Dr. VEMO Bertin Narcisse of the University of Dschang for the helpful guidance and encouragement during the time of study; and the Director of SOCAPALM for his support to purchase the rubber seeds.

\section{Authors' contribution}

MA conceived the study, designed the study, collected data, contributed in data analysis, and writing the manuscript, coordinated the inputs of all the other authors; DFH performed critical reviewing of the manuscript and supervision of the study; FF, TA and TJ contributed in conception of the study and performed critical reviewing of the manuscript; CMA contributed in design of study, data collection and writing the manuscript; MM contributed in data analysis and performed critical reviewing of the manuscript; KMH contributed in conception of the study and critical reviewing of the manuscript.

\section{Competing interest}

The authors declare they have no conflict of interest. 


\section{REFERENCES}

Aguihe PC, Kehinde AS, Ospina-Rojas Cl, Murakami AE (2017). Evaluation of Processing Methods of Rubber (Hevea brasiliensis) Seed Meal for Use as a Feed Ingredient for Broiler Chickens. Journal of Poultry Research, 14(1):20-27. Link: https://www.turkishpoultryscience.com/tr/download/article-file/420023

Ahaotu E (2018). Nutritional Evaluation of Rubber Seed Meal with Blood Meal in Broiler Rations. International Journal of Animals Science, 2(3): 10-26. Link: https://smjournals.com/animal-science/fulltext/ijas-v2-1026.php

Akinmutimi A H (2007). Effects of cooking periods on the nutrient composition of velvet beans (Mucuna pruscens). In: Proceeding of the $32^{\text {nd }}$ Annual Conference of the Nigeria Society for Animal production, March 18th-21st. University of Calabar, Calabar, pp. 223-236. https://scholar.google.com/scholar?hl=fa\&as sdt=0\%2C5\&q=Effects+of+cooking+periods+on+the+nutrient+composition+of+velve t+beans+\%28Mucuna+pruscens\%29.+In\%3A+Proceeding+of+the+32nd+Annual+Conference+of+the+Nigeria+Society+for+Animal+ production\&btnG $=$

Alao BO, Falowo AB, Chulayo A and Muchenje V (2017). The Potential of animal by-products in food systems: production, prospects and challenges. Sustainability, 9: 1089. DOI: https://doi.org/10.3390/SU9071089

Amanidja BD, Soro D, Komara M (2019). Effects of the rate of rubber seed cake (Hevea brasiliensis) on the zoo technical performance of local ducks (Cairina moschata linnaeus. 1758) in semi intensive breeding in Côte d'lvoire. International Journal of Advances in Scientific Research and Engineering, 5(4): 170-176. DOI: http://doi.org/10.31695/IJASRE.2019.33142

AOAC (Association of Official Analytical Chemist) (2000). Official method of analysis. 17 th edition. A.O.A.C. Washington D.C. https://www.sigmaaldrich.com/catalog/product/aldrich/z423645?lang=en\&region=IR

Atchibri L O, Atcho 0, Kouakou B and Keli J (2008). La graine d'hévéa appauvrie en acide cyanhydrique par la méthode de triple séchage offre un tourteau propre à la consommation de la poule pondeuse. Revue Africaine de Santé et de Productions Animales, 6 (3-4): 195-198.

https://scholar.google.com/scholar?hl=fa\&as sdt=0\%2C5\&q=La+graine+d\%27h\%C3\%A9v\%C3\%A9a+appauvrie+en+acide+cyanhy drique+par+la+m\%C3\%A9thode+de+triple+s\%C3\%A9chage+offre+un+tourteau+propre+\%C3\%A0+la+consommation+de+la+poule + pondeuse\&btnG $=$

Chakam V (2006). Effets du traitement et du taux d'incorporation sur l'utilisation du Niébé (Vigna unguilata) par des poulets de chair en finition. Thèse de Master of Science en Biotechnologie et Production Animales. Thesis in Msc. Of Animal Biotechnology, Université de Dschang, Cameroon, 75 p.

Chang C C, Yang M H, Wen H M, Chern J C (2002). Estimation of total flavonoïd content in propolis by two complementary colorimetric methods. Journal of Food Drug Analysis, 10 (3): 178-182. DOI: https://doi.org/10.38212/2224-6614.2748

Chanjula P, Siriwathananukul Y, Lawpetchara A (2010). Effects of feeding rubber seed kernel and palm kernel cake in combination on nutrient utilization, rumen fermentation characteristics, and microbial populations in goats fed on briachiaria humidicola hay-based diets. Asian-Australasian Journal of Animal Sciences, 24(1): 73-81. DOI: https://doi.org/10.5713/ajas.2011.10171

Cunha L and Freire J P (1993). Effects of the total or partial replacement of soya meal by Vicia benghalensis on the digestibility caecotrophy and nitrogen balance in adult rabbits. World Rabbit Science, 1(1): 31-36. DOI: https://doi.org/10.4995/wrs.1993.193

Defang F H, Keambou T C, Manjeli Y, Teguia A and Pamo T E (2014). Influence de la farine des feuilles de Leucaena leucocephala sur les performances de croissance des lapereaux. International Journal of Biological and Chemical Sciences, 8(4): 1430-1437. DOI: https://doi.org/10.4314/ijbcs.v8i4.7.

Deng J, Mai K, Chen L, Mi H and Zhang L (2015). Effects of replacing soybean meal with rubber seed meal on growth, antioxidant capacity, non-specific immune response and resistance to Aeromonas hydrophila in tilapia (Oreochromis niloticus $\times 0$. aureus). Fish and Shellfish Immunology, 44(2): 436-444. DOI: https://doi.org/10.1016/j.fsi.2015.03.018

Eka HD, Tajul AY and Wan Nadiah WA (2010). Potential use of Malaysian rubber (Hevea brasiliensis) seed as food, feed and biofuel. International Food Research Journal, 17: 527-534. Link: http://www.ifrj.upm.edu.my/17\%20(03)\%202010/IFRJ-2010-527534\%20tajul\%20malaysia\%20ok.pdf

Farr HM, Donkoh A, Boateng M, and Mensah KB (2019). Effect of variously-processed rubber seed meals on reproductive performance: The use of Sprague-Dawley laboratory rats as model for pigs. Journal of Animal Science and Veterinary Medicine, 4(5): 167-172. Doi: https://doi.org/10.31248/JASVM2019.144

Govindappa M, Naga S, Poojashri M N, Sadananda T S, Chandrappa C P, Gustavo S, Sharanappa P and Kumar AN (2011). Antimicrobial, antioxidant and in vitro anti-inflammatory activity and phytochemical screening of water extract of Wedelia trilobata (L) Hitchc. $\begin{array}{llllll}\text { Journal of Medicinal } & \text { Plants } & \text { Research, } & \end{array}$ https://academicjournals.org/article/article1381318404_Govindappa\%20et\%20al.pdf

https://scholar.google.com/scholar?hl=fa\&as_sdt=0\%2C5\&q=Effects+of+Soaking+on+the+Nutritive+Value+of+Raw+Full+Fat+Rubber+ $\% 28$ Hevea+Brasiliensis\%29+Seed.+Nigerian+Journal+of+Agriculture\%2C+Food+and+Environment\&btnG=

ISO 6703-2 (1984). Qualité de l'eau-Détermination des cyanures totaux et des cyanures libres par analyse en flux contin, 1: 11p. link: https://www.iso.org/obp/ui/\#!iso:std:52208:fr

lyayi EA, Kluth $\mathrm{H}$ and Rodehutscord M (2008). Effects of heat treatment on anti-nutrients and precaecal crude protein digestibility in broilers of four tropical crop seeds. International Journal of Food Science and Technology, 43 (8): 610-616. https://doi.org/10.1111/j.1365-2621.2007.01495.x

Joint FAO/WHO Expert Committee Report on Food Additive (JECFA) (1993). Cyanogenic glycosides. In: Toxicological Evaluation of Certain Food Additives and Naturally Occurring Toxicants. 39th Meeting of the Joint FAO/WHO Expert Committee on Food Additives (WHO Food Additive Series 30). World Health Organization. Geneva. Link: https://apps.who.int/iris/bitstream/handle/10665/41742/9241660325_eng.pdf?sequence=1\&isAllowed=y

Koné GA, Kouakou N'Goran DV, Angbo-kouakou CE, Kouame KB, Yeboue FD and Kouba M (2016). Etude préliminaire de la valorisation des tourteaux d'hévéa, d'anarde et de pourghère chez les porcs durant la gestation et la lactation. European Scientific Journal, 12 (30): 11-22. DOI: https://doi.org/10.19044/esj.2016.v12n30p1

Lalabe BC, Olusiyi JA and Afolabi KD (2017). Effects of Soaking on the Nutritive Value of Raw Full Fat Rubber (Hevea Brasiliensis) Seed. Nigerian Journal of Agriculture, Food and Environment, 13(2): 78-82.

Lounaouci-Ouyed G, Berchiche M, and Gidenne T (2014). Effects of substitution of soybean meal-alfafa-maize by a combination of field bean or pea with hard wheat bran on digestion and growth performance in rabbits in Algeria. World Rabbit Science, 22(2): 137-146. DOI: https://doi.org/10.4995/wrs.2014.1487 
Niba AT, Meutchieye F, Fon D, Laisin A G, Taboh H, Njakoi H, BelaTomo A, Maass B L, Djikeng A and Manjeli Y (2012). Current situation of cavy production in Cameroon: Challenges and opportunities. Livestock Reseacrh Rural Development, 24 . Article \#194. http://www.Irrd.org/Irrd24/11/niba24194.htm

Nwokolo E, Bragg DB and Sim JS (1988). Dietary utilization of rubber seed oil by growing chicks. Tropical Science, 27: 195-204. https://agris.fao.org/agris-search/search.do?recordID=US201302684397

Pauwels M J, Van R E and Verloo M (1992). Manuel de laboratoire de pédologie: Méthodes d'analyse de sols et de plantes, équipement, gestion de stock de verrerie et de produits chimiques. Publié à Yaoundé par le centre universitaire de Dschang. Département des sciences du sol, Cameroon. https://biblio.ugent.be/publication/223183

Ramdé-Tiendrébéogo A, Tibiri A, Hilou A, Lompo M, Millogo-Kone H, Nacoulma 0 and Guissou I (2012). Antioxidative and antibacterial activities of phenolic compounds from ficus su forssk and ficus sycomorus (Moraceae): potential for sickle cell disease treatment in Burkina Faso. International Journal of Biological and Chemical Sciences, 6(1): 328-336. DOI: https://doi.org/10.4314/ijbcs.v6i1.29

Rivière R (1991). Manuel d'alimentation des ruminants domestiques en milieu tropical. Collection manuel et précis d'élevage. Ministère de la coopération et du développement, 529p. https://agritrop.cirad.fr/381188/

Sharma B B, Saha R K and Saha H (2014). Effects of feeding detoxified rubber seed meal on growth performance and haematological indices of Labeo rohita (Hamilton) fingerlings. Animal Feed Science and Technology, 193: 84-92. https://doi.org/10.1016/j.anifeedsci.2014.03.008

Sugiharto S, Yudiarti T, Isroli I, Widiastuti E (2018). The potential of tropical agro-industrial by-products as a functional feed for poultry. Iranian Journal of Applied Animal Science, 8(3): 375-385. Link: http://ijas.iaurasht.ac.ir/article 542614.html

Suprayudi M A, Inara C, Ekasari J, Priyoutomo N, Haga Y, Takeuchi T and Satoh S (2015). Preliminary nutritional evaluation of rubber seed and defatted rubber seed meals as plant protein sources for common carp (Cyprinus carpio L.), juvenile diet. Aquaculture Research, 46(12): 2972-2981. DOI: https://doi.org/10.1111/are.12452

Syahruddin E, Herawaty R and Ningrat R.W.S (2014). Effects of substitution of leaves and seeds of rubber (Hevea brasilliensis) fermentation with soybean meal on the performance of broilers. Pakistan Journal of Nutrition, 13(7): 422-426. https://dx.doi.org/10.3923/pjn.2014.422.426

Tendonkeng F, Boukila B and Pamo T E (2011). Potential for using Leucaena leucocephala or Manihot esculenta leaves for supplementing feeding of goats in West Cameroon. Iranian Journal of Applied Animal Science, 1(3): 143-147. http://ijas.iaurasht.ac.ir/article_514006_3114afbb15f9d6c734521938a26a4ba9.pdf

Thangaraj P (2016). Proximate composition analysis. Pharmacological Assays of Plant- Based Natural Products. Progress in Drug $\begin{array}{llllll}\text { Research, Springer } & \text { International } & \text { Publishing, } & \text { Switzerland. } & \text { 71p. }\end{array}$ https://www.springer.com/gp/book/9783319268101\#aboutBook

Udo MD, Ekpo U and Ahamefule FO (2018). Effects of processing on the nutrient composition of rubber seed meal. Journal of the Saudi Society of Agricultural Sciences, 6: 1-5. http://dx.doi.org/10.1016/j.jssas.2016.06.001

Wafar RJ, Yakubu B and Lalabe BC (2017). Effects of Feeding Raw Kapok (Ceiba pentandra) Seed Meal on the Growth Performance, Nutrient Digestibility, Carcass and Organ Weights of Weaner Rabbits. Asian Research Journal of Agriculture, 5(3): 1-8. https://www.journalarja.com/index.php/ARJA/article/view/1323 